Irina Sferdian

associate professor

West University of Timişoara, Faculty of Law

\title{
Periodic Property in the Regulation of the Romanian Civil Code
}

Debreceni Jogi Műhely, 2014. évi (XI. évfolyam) 3-4. szám (2014. december 30.)

Periodic, or time-sharing, property is established by the Romanian Civil Code as a form of joint ownership, also called co-ownership, which is characterized by an intellectual division of the right, with the particular mention that, in fact, the fraction of the right corresponds to a fraction of time in which the use over the entire good is exercised exclusively by each of the co-owners. The time intervals, be it equal or unequal, in which is shared the use of the common good is expressed through the division of the right in corresponding fractions. Therefore, not all the prerogatives of the property right are exercised successively, in time, but only the attribute of use. Moreover, it is possible for some elements of the use to be exercised jointly. Thus, the expenses related to the use shall be borne jointly by the holders, even if, afterwards, they are going to be divided among them, according to the rightful share[1].

From among the prerogatives of the periodic property right, only its use is exercised successively and rhythmically. Possession, as the element of the property right which expresses, on an intellectual level, the appropriation and enjoyment of the good, is exercised continuously, regardless of the successive intervals of the good's use. Similarly, continuously, is exercised the legal provision over the rightful share by its holder. The latter may, at any time, dispose of his/her rightful share, not having to wait for the appropriate interval of use.

Also, the material disposition - by which the substance of the good gets consumed, since the integrity of the good, as well as its use, are affected - can only be continuous, and not successive, because it requires the consent of all the co-owners, which supposes exceeding the time slot corresponding to each and every one of them.

As it is a forced joint ownership, it cannot be terminated by judicial partition. Such a partition would affect the stability and continuity of periodic property.

\section{The notion of periodic property}

Periodic property is a legal institution regulated as novelty in the current Romanian Civil Code, which entered into force on October $1^{\text {st }} 2011$, in Chapter V of Title II (Private property) from Book III (On goods), but the civil law doctrine and practice have acknowledged its existence as a modality of the property right even before, due to a regulatory gap in the old Romanian Civil Code from 1864.

The civil law doctrine has defined periodic property as a modality of the property right in which two or more persons exercise, successively and repetitively, the attribute of use specific to the property right over a movable or immovable good, in determined time intervals, equal or unequal[2].

On the grounds that periodic property is a form of joint ownership, some authors were of the opinion that the use of the phrase "space and temporal joint ownership" might be more appropriate[3].

In our opinion as well, periodic property represent a form of joint ownership. It is impossible to exercise, over one and the same good, several exclusive property rights, but it is possible to have several holders of a single property right, which is divided among them in determined shares (the case of joint ownership) or indeterminate shares (the case of joint indivisible ownership) . 
In the case of periodic property, the object of the property right is represented by a movable or immovable property, and its holders can be both natural and legal persons. As shown in Article 687 of the Civil Code, the regulations referring to periodic property from the Code Civil shall apply with priority, in the absence of other special provisions, whenever several people exercise successively and repetitively the attribute of use, specific to the property right, over a certain good for a determined period of time.

Therefore, periodic property is characterized by two essential features: 1) the property right has several holders; 2) the prerogatives of this right are successively exercised by the holders in determined intervals of time, be it equal or unequal.

Unlike regular joint ownership, which supposes a simultaneous and concurrent exercise of property over the entire good by all the co-owners and which ensures and allows the use of the entire good by each and every one of them, all throughout the duration of the joint ownership, in the case of periodic property, the use is exercised over the entire good, but over limited periods of time, successive and repetitive, which exclude the possibility of a simultaneous and concurrent use of the property right.

This explains the fact that periodic property is conceived, in the Romanian Civil Code, as a form of forced joint ownership, which cannot be terminated by means of judicial partition. Such a partition would affect the stability and continuity of periodic property.

In the case of periodic property as well, being in the presence of multiple holders of the property right, we deal with joint ownership, with an intellectual division of the right, with the remark that the fraction of right corresponds, in reality, to a fraction of time in which the use of the entire good is being exercised, exclusively, by each of the co-owners. The time intervals, equal or unequal, in which is shared the use of the common good is expressed by dividing the right into corresponding fractions. Therefore, not all the prerogatives of the property right are exercised successively in time, but only the attribute of use. Furthermore, it is possible for some elements of use to be exercised jointly. Thus, the expenses related to use are borne jointly by the holders, even if they are afterwards divided among them according to the share of right[4].

Out of all the prerogatives of the periodic property right, only the use is exercised successively and rhythmically. Possession, as the element of the property right which expresses, on an intellectual level, the appropriation and enjoyment of the good, is exercised continuously, regardless of the successive intervals of the good's use. Similarly, also continuously, is exercised the legal provision over the rightful share by its holder. The latter may, at any time, dispose of his/her rightful share, not having to wait for the appropriate interval of use.

Also, the material disposition, by which gets consumed the substance of the good, since the integrity of the good, as well as its use, are affected, can only be continuous, and not successive, since it requires the consent of all the co-owners, which supposes exceeding the time slot corresponding to each and every one of them.

Like any forced joint ownership, periodic property cannot be terminated through judicial partition, but only through amicable partition.

We have shown that the provisions regarding periodic property shall apply in all situations where there are several holders of the property right over one and the same good and where its use is shared among them, for equal or unequal time durations. The question arises whether one shall apply the rules of periodic property in the case of a regular joint ownership where, subsequent to its birth, the co-owners agree to a partition of the use according to time slots. If, by means of an act subsequent to the birth of a regular joint ownership, the co-owners establish, by mutual agreement, a successive manner of use, without specifying that this shall be done according to the shares of ownership and that it has a periodic nature, we believe that 
their intention should only be interpreted as an amicable partition of use, and not as an act of birth of a periodic property.

We believe that, in this case, one should analyse the real intention of the co-owners, since, in the case of the regular joint ownership, the partition of use is merely a way to ensure a better use of the good and is not linked to the essence of this form of property, as is the case for the periodic property. If, however, the parties' intention was a division of the property right on time slots, so that the shares from the property right pertain to the time intervals in which they would exercise the use, the rules of the periodic property shall apply. Given that the applicable legal regime is different, the discovery of the real intention of the co-owners is crucial.

\section{The source of periodic property}

According to Article 688 of the Civil Code, "Periodic property arises under a legal act, with the corresponding application of the provisions regarding land registry".

According to some authors, the periodic property cannot be acquired through a legal fact in the restricted sense[5].

The periodic property right can arise through legate or agreement. When it is born by means of a legate, the testator's will transforms a plain and regular property into a periodic property. One should not confuse the birth of the periodic property through a legate with the transmission, either by legate or by legal inheritance, of the periodic property, because only in the first case the periodic property arises out of the legate, whilst in the second case, the periodic property pre-exists to the legate[6].

Periodic property can be acquired by agreement, in an original way, by the construction of a building by the co-owners, who agree upon this form of joint ownership from the very beginning. We say that it is a case of original acquisition because the right arises by agreement of the parties, even if it materializes itself by the fact of construction of the building.

In other situations, a periodic acquisition is also possible by means of the purchase of a good found in a plain and regular property in the patrimony of its transmitter, in which case, at the very moment when the transmission of the right occurs, the change in the form of property also takes place, from a plain and regular into a periodic one.

Also, it is possible that the transmitter of a good transforms the property right from a plain and regular one into a periodic property among the acquirers, as in the case of a donation where the donor gratifies the beneficiaries by shares of time from the property right over the donated good.

Periodic property can also be acquired through the alienation by one of the co-owners of his/her share of the periodic property right, the acquirer taking his/her place in the joint ownership.

Finally, the holders of a regular right of joint ownership can transform their property right into a periodic joint ownership, with a forced nature, in the situation in which they would be interested in avoiding a judicial partition. It is considered that, in this case, the co-owners can bypass the restriction regarding the limited nature of the agreements of suspension of the partition for a maximum period of 5 years. This agreement does not represent a derogation from the imperative provisions regarding the suspension of partition, since the parties modify the very form of property, which is subject to other rules, including the impossibility of the judicial partition[7].

The object of the periodic property may be a movable or immovable good. In the case if an immovable, the periodic property right is acquired by registration in the land register, except for the cases provided by the legislator in Article 887 of the Civil Code, when the acquisition of property occurs without registration and with the amendment of postponing the 
enforcement of the provisions regarding the constitutive of right nature of the registration in the land register through Article 56 of Law no. 71/2011 on the implementation of the Civil Code.

\section{The exercise of the periodic property right}

Similarly to the co-owner from regular joint ownership, according to Article 689 of the Civil Code, the holder of a share from the periodic property has an exclusive property right in relation to his/her allotted time slot. This explains why he/she can conclude by oneself, validly, acts of disposal (e.g. sale, mortgage) or administration (rental) relating to the time slot on which he/she is the owner. The acquirer shall become his/her substitute in the periodic property during the time slot belonging to the transmitter.

The holder of a time slot in the periodic property, however, will not be able to conclude acts by which to commit the share of property belonging to other holders, namely pertaining to another time slot. For this reason, the acts of administration, in their turn, can only be concluded by a co-owner as concerns the entire good for the period of time in which the former exercises its use. In this respect, Article 689 para.(2) of the Civil Code provides that "The acts of administration or disposal regarding the share of the property right related to another time interval are unenforceable against the holder of the respective share".

The legislator does not mention anything about the acts of preservation whose effect occurs over a period of time which exceeds the interval corresponding to the co-owner who concludes the act. With reference to the provisions of Article 689 para.(2) of the Civil Code, which sanctions with unenforceability only the acts of administration and disposal regarding the share from the property right corresponding to the time interval which does not belong to the contracting co-owner, it results that these acts, given their non-injurious nature, are enforceable on all the other holders of shares from the periodic property.

In the matter of periodic property, the legislator does not provide the possibility to conclude an act of administration over the entire good with the consent of the majority of the shares from the property right. Such an act would be possible if it produced its effects only for the time interval corresponding to the shares from the right which belong to the holders of the majority of shares.

Decisive in assessing the validity of an act of administration or disposal is that its effects in time do not exceed the period incumbent to the holder who concludes the act. Only by means of a unanimous consent is it possible to have an act of administration or disposal over a common good which covers all the time slots owned by the holders of the periodic property.

\section{The sanction for the failure to comply with the conditions regarding the conclusions of the acts of administration or disposal}

Regarding the sanction applicable to such acts, Article 689 para.(2) of the Civil Code refers to the provisions of Article 642 para.(2) and Article 643 of the Civil Code, applicable to regular joint ownership.

a) Unenforceability

According to Article 642 para.(1) of the Civil Code, the legal act concluded with the disregard of the rules regarding the consent of the co-owners is unenforceable to the co-owner who did not give his/her consent upon its conclusion. This means not only the respective co-owner does not have any rights and obligations following the conclusion of this agreement for which he/she did not give his/her consent, since this is, however, the natural effect of the principle of relativity of the legal civil act, but also the fact that this act is not enforceable against him/her, not even as a legal fact in a restricted sense, as it would be in the case of the other third parties. Consequently, the unenforceability of the act to the co-owner whose interests were 
harmed means that he/she is entitled to disregard the legal situation which arises from its conclusion and to act accordingly.

The Romanian legislator, in keeping with the opinion of some French authors[8], but also of some Romanian authors[9], despite the majority opinion from our doctrine and case-law, which saw in partition the only possibility for solving the problem of the non-contracting coowner, provides the sanction of unenforceability, applicable throughout the life of the joint ownership, in order to avoid forcing the co-owners to resort to its termination through partition when they want to maintain the joint ownership.

\section{b) Possessory action}

In case the co-owner who has not given his/her consent to the conclusion of the act wants to preserve the state of joint ownership, he/she can promote, pursuant to Article 642 para.(2) of the Civil Code, a possessory action against the third party who is in possession of the good, as a result of the act concluded with the other co-owners. The possessory action has the legal nature of an act of preservation, and, although he/she will be able to promote it himself/herself, the restitution of the possession of the common good is done for the benefit of all co-owners because, otherwise, the co-owner plaintiff would acquire an exclusive possession over the good, which could at a later stage entitle him/her to an exclusive property over the entire good, by means of acquisitive prescription.

Since it would be unnatural to remain unsanctioned, the co-owners who have concluded an act with third parties in disregard of the conditions provided in Article 641 of the Civil Code would be liable to pay compensation for the damage caused on the ground of tort liability.

The possessory action to which is entitled the co-owner whose consent was ignored upon the conclusion of the act supplements the unenforceability sanction provided by the legislator in his/her favour. The mere unenforceability of the act would prove ineffective unless the law allowed the intervention with the purpose of annihilating the effects of this act. For the coowner, a declaratory action regarding the unenforceability of the act is not enough; furthermore, it is necessary to remove the effects of the concluded act.

The law does not provide differentiated sanctions according to the nature of the act concluded between the co-owners and the third parties and so the use of unenforceability, together with a possessory action for the re-entry into the possession of the common good, applies both for the acts of administration concluded in disregard of the principle of majority of the shares or without the express consent of the co-owner whose use of the good is substantially limited or in the burden of whom are established excessive obligations, and in the case of the acts of disposal concluded in violation of the unanimity rule.

However, given that the possessory action does not affect the property right itself, and that the unenforceability does not deprive of effects the act conclude by some of the co-owners with a third party, we believe that nothing prevents the co-owner who has not entered into the contract to defend his/her right alienated without his/her will, by means of an action for recovery which he/she will introduce against the third party possessor. The filing of an action for recovery is justified especially when the conditions for the promotion of a possessory action are not satisfied.

c) Action for recovery

The possibility to resort to the action for recovery before partition does not result expressly, but implicitly, from the provisions of Article 643 para.(1) of the Civil Code, which stipulate the right of the co-owner to stand alone in trial in actions for recovery. As in the case of possessory actions, the upholding of an action in recovery will determine the restitution if a common - and not exclusive - possession for all the co-owners over the common good.

The legislator does not expressly provide a sanction for the act of alienation of the entire right over the common good in violation of the unanimity rule. 
The specialized doctrine has considered such alienations as valid, under the resolutive condition that the good is allocated, at partition, in the share of another co-owner than the one who disposed of the common good, the nullity of the act being considered a sanction which does not apply in the field of joint ownership, governed by specific rules[10]. Some authors[11] have admitted that such contracts cannot be considered as affected by a resolutive condition since it would equate a recognition of their validity until the partition, or the coowner who was responsible for the alienation could not have disposed validly of the entire property right over the common good, since he/she only held a share of the respective right. For this reason, the act of alienation must be regarded as concluded under the suspensive, and not resolutive, condition of the granting, upon partition, of the indivisible good to the alienating co-owner. We would find ourselves before an atypical condition, not regulated by law. The act will not be able to produce, in this case, any effects until the partition.

Due to the unenforceability towards the non-contracting co-owner, the third party acquirer will not be able to invoke, in relation to the former, the validity of the alienation under suspensive condition.

However, such an opinion may be admitted also in relation to the new regulation, but only if the non-contracting co-owner opts for partition without having promoted an action for recovery since, in this case, the act of alienation concluded without his/her consent will be able to produce effects if, upon partition, the good is attributed entirely to the co-owner responsible for the alienation.

This solution is in line with the provisions of Article 680 of the Civil Code, which establishes the ex nunc effect of partition, abandoning its retroactive effect. One may thus claim that the act of alienation shall be deemed validly concluded under the suspensive condition that the good be allotted, by means of the partition, to the person responsible for its alienation.

Article 1683, governing the sale of another's property in the current Civil Code, provides in para.(1) that the sale of a determined individual good which is the property of a third party is valid, the seller being bound to ensure the conveyance of the property right from its holder to the buyer. According to para.(3), when the good is found in joint ownership and one of the coowners alienates it in its entirety without the consent of the others, the contract will be valid under the condition of ensuring the subsequent conveyance of the property right to the buyer. In case the seller fails to perform this obligation, the buyer may require, in addition to damages, at his/her choice, either the reduction of the price in proportion to the share which he/she did not acquire, or the termination of the agreement, in case he/she would not have bought had he known that he would not acquire the property over the entire good.

From the moment of the agreement between the co-owner seller and the buyer, the only one to be conveyed validly is the share from the property right which belonged to the seller. The buyer will substitute validly in the joint ownership only as regards this share of the right. However, given the right of the buyer to choose between maintaining the agreement for this share of the right, with a price reduction, and seeking the rumination of the sale on the grounds that, under these conditions, he/she would no longer have completed the sale, the legal act concluded will only be enforceable to the other co-owners until after the buyer will have expressed his/her option.

In the case of periodic property, Article 689 of the Civil Code distinguishes between coowners and the third party acquirer regarding the sanction applicable in the event of the conclusion of the acts of administration and disposal without observance of the legal conditions, namely when referring to other time intervals than the ones corresponding to the shares of the contracting co-owners. Thus, according to Article 689 para.(3) of the Civil Code, if for the co-owners the act is unenforceable, in the relations with bona fide co-contracting third parties, the act will be annullable. We note that the bona fide third party purchaser will be able to bring an action for annulment, asking either for a partial nullity, if he/she wants to 
preserve the act for the shares which can be validly conveyed, or a total nullity. However, we do not understand the inconsistency of the legislator as regards this sanction, namely the reason why, in the case of regular joint ownership, the third party buyer can opt for termination, and in the case of periodic property, for nullity.

Unlike the contracting third party, the co-owner who was not part of the act may not bring an action for annulment of the act, the legislator considering it sufficient to invoke the unenforceability of the concluded act and to benefit from other procedural remedies in order to achieve his/her right (possessory action, action for recovery).

\section{Lawsuits available to the co-owner}

In the doctrine and case-law, one has consistently supported the idea that since in joint ownership only the right is divided among the co-owners, not the good which represents the object of this right, a co-owner cannot stand alone in court in those actions which have the nature of acts of disposal, through which one follows the recognition of an exclusive possession over an indivisible good.

It was however considered that the possessory action was admissible, even if brought by a single co-owner, provided it was directed against a third party, and not against another coowner.

The admissibility of a possessory action brought by a co-owner against a third party was explained by the fact that it is an act of preservation of the state of joint ownership, and among the co-owners there exists a relation of perfect representation[12]. For this reason, the admission of such an action benefits all co-owners, because, due to the presumption that he/she acts for the others as well, the co-owner cannot ask for and cannot obtain the recognition of an exclusive possession over the common good.

The provisions of Article 643 of the Civil Code stipulate the possibility of the co-owner to stand alone in trial in any action regarding joint ownership, having legal standing both as a plaintiff, and as a defendant. The regulation also applies in the matter of periodic property, since Article 689 para. (2) of the Civil Code refers to it.

In order not to harm the rights of the co-owners who do not participate in the trial, the law provides that only those decisions which are favourable to them will have enforceability upon them, excluding the unfavourable ones. Therefore, the legislator regulates a type of imperfect representation among the co-owners by the fact that it limits itself only to the judgments favourable to the joint ownership[13].

Due to the imperfect representation, the rights of the co-owners in default are in no way harmed, and they can, at any time, each of them separately or together, bring an action on the same matter, without being impeded by the exception of res judicata.

When the co-owner has the quality of plaintiff, the law entitles the defendant to require the introduction in the action of the other co-owners as well, in order to avoid a series of trials based on the same object.

The express regulation within Article 643 para.(1) of the Civil Code of the possibility for a co-owner to bring along an action for recovery of the joint ownership is not above criticisms.

Such an action was considered, by most authors, inadmissible, because a co-owner is merely a holder of an ideal share from the property right and cannot claim the return of the good in his/her patrimony, since he/she did not have and, therefore, one cannot return to him/her the material possession of the entire good. He who does not have something materially determined cannot claim something materially determined[14].

It was also claimed that the action for recovery is not a simple act of preservation because it requires expenses which are not at all trivial and documentary evidence which might prove difficult to manage by a single co-owner. Moreover, the co-owner has at his/her disposal the judicial partition of the use, in which, together with the other co-owners, he/she can bring into 
the action the third party possessor as well, for the enforceability of the judgment. On this occasion, the plaintiff will receive a materially determined part of the good and will be able to deter any attempt by the third party to acquire the property right by means of useful possession. The argument according to which it is necessary to admit the possibility of an action for recovery made by a co-owner in order to stop the running of the acquisitive prescription of the third party is thus dismissed[15].

In a contrary view[16], it is argued that the action for recovery has the nature of an act of preservation, and not of disposal since such action interrupts the acquisitive prescription in favour of the third party who, by definition, possesses the indivisible good animus sibi habendi. One thus avoids the loss of the joint ownership in all situations where the action cannot be promoted because some of the co-owners oppose or cannot be found, and the nonowner who possesses the indivisible good can acquire its acquisitive prescription by means of useful possession.

Since each and every co-owner of the indivisible good is allowed to promote an action for the partition of the use of the good action all the other co-owners, it would be totally unnatural not to allow the promotion of the action for recovery against the third party who owns the good without due title or pursuant to an act which is unenforceable to the non-contracting coowner plaintiff[17].

To use the action for partition of the use so that, subsequently to the allotment of the indivisible good, one might promote an action for recovery, would transform the partition from a possibility of the co-owners of the indivisible good into an obligation, indirectly imposed by the co-owners who would oppose the recovery[18].

Possessory and petitory actions cannot be brought by co-owners against each other because they have concurrent rights which suppose, individually, the common and not exclusive ownership of the respective indivisible good.

If the sued defendant declares that he/she is holding the good for another person, who does not have the quality of a co-owner, the latter will be brought in the action, and the trial will be held according to the rules of recovery. If the defendant is holding the good for another coowner, even if the latter is brought in the action, the trial can no longer be a recovery, which is inadmissible among co-owners, but will discuss with the unenforceability of the act concluded with the third party. This unenforceability would be purely platonic if the co-owner plaintiff wouldn't be offered the opportunity to enter into the possession of the common good held by the third party[19].

Although the new regulation does not expressly qualify the action for recovery as an act of preservation, the view embraced is that a co-owner may bring one along an action for recovery, but the negative effects that the dismissal of the action might have upon the other co-owners who did not have the quality of plaintiff are annihilated.

We could say that, under the conditions in which the law takes into account the possible damage that could be caused by the dismissal of the action for the co-owner who was not part in the trial, we can infer that the legal nature of such an action could not be that of an act of preservation, since an act of preservation is devoid of any harmful effect. The mere fact that the law restricts the effects of the unfavourable judgment only to the co-owner who was part of the trial means, implicitly, that it does not seek to assign the nature of an act of preservation to such action. On the other hand, this qualification remains irrelevant in the situation in which the law allows its promotion by a single co-owner and limits its effects only as regards the latter.

The co-owners may conclude, with everyone's consent, an act of administration of the common good in periodic property, under the same conditions as the holders of a regular joint ownership. The administrator can be one of the co-owners or a third party, natural or legal person. 
The administration agreement must comply with the rules of periodic property, the expenses related to the administration being borne by them in proportion to the share of the right which they hold.

Although the legislator sends expressly only to the provisions of para.(2) of Article 644 of the Civil Code, which provide the possibility of termination of the administration agreement by each of the co-owners, the following are applicable in this case: the condition of the unanimous consent of all the co-owners, as well as the prerequisite of the registration in the land register of the administration agreement and of the statement of unilateral withdrawal made by a co-owner, whenever the object of the periodic property is represented by an immovable.

\section{The holder of the periodic property's sanction for non-compliance with the obligations}

Periodic property is a forced joint ownership. No co-owner, dissatisfied with the functioning of his/her relationship with the co-owners that might prevent him/her in the corresponding use of his/her share of the right, will be able to require the cessation of this property through a legal action in partition.

As we have seen, it is possible to bring a possessory action, an action in relative nullity of the acts concluded with third parties disregarding the legal provisions and even an action for recovery.

For a better functioning of this special form of joint ownership, Article 691 para.(1) of the Civil Code stipulates the obligation to the payment of a compensation by the co-owner who violates the legal provisions regarding periodic property. Since the law does not distinguish, any breach by a co-owner of an obligation provided in his/her burden may entail the payment of damages. We believe however that the legislator had in mind, in particular, the obligation which falls upon every co-owner in his/her relationships with the others, related to providing a useful and undisturbed use of the common good. Naturally, the co-owner requesting the payment of such compensation will have to prove the damage suffered.

Article 691 para. (2) of the Civil Code regulates a second sanction, more severe, which is not found in other forms of joint ownership, not even forced. Thus, the measure of the exclusion is provided by the legislator as a sanction for the serious disturbance which a co-owner might cause in exercising periodic property.

The sanction of the exclusion is an exclusively judicial one, and its application by the court requires the cumulative fulfilment of two conditions: 1) a co-owner must cause a serious disturbance in the exercise of the right of periodic property and 2) the existence of a co-owner or a third party willing to buy the share of the excluded party.

The necessity to cumulatively fulfil the two conditions ensues from the corroborated reading of para. (2) and (3) of Article 691 of the Civil Code.

As regards the first condition, the legislator does not specify what is meant by serious disturbance in the exercise of periodic property. The proof of the disturbance must be made by the co-owner seeking to obtain the exclusion from the periodic property of the author of the disturbance. One cannot take the measure of the exclusion unless the person who caused the disturbance is one of the co-owners, and not a third party, even if the latter would be the holder of a personal right of use of the good for a certain period of time. The seriousness of the disturbance is a matter of fact to be determined by the court concretely, for each case.

The second condition is fulfilled only if there is a co-owner or a third party interested in buying the share from the property right which belongs to the excluded co-owner. If this condition is not met, the court may not order the exclusion, regardless of the seriousness of the disturbance of the periodic property. 
The justification of the second condition consists in the need to maintain the state of forced joint ownership, producing a subrogation of the excluded co-owner with the one who will buy his/her share of the right.

The court will assess the meeting of the conditions for exclusion in a ruling admitting in principle such measure, which can be appealed separately.

The sale of the share can be achieved amicably, at a price mutually agreed upon by the parties. Only when the parties do not agree will the court determine the sale price. Although the legislator speaks of a forced sale, this is not done through the public tender procedure via a bailiff; it is a sale mediated by the court. The court will be the one which sets the price, based on a specialized expertise, determines at which bank the price will be deposited and it is the court again which, thereafter, pronounces a judgment which substitutes the sale agreement.

When the judgment becomes final, the acquirer will be able to register his/her right in the land register, and the conveyor will be able to collect the price from the bank where it was deposited.

\section{Termination of the periodic property}

The right of periodic property ceases through the removal from the land register. The termination through removal of the period property is consistent with the constitutive effect of right of the entries in the land register and is provided by Article 885 para.(2) of the Civil Code, according to which "Property rights are lost or extinguished only through their removal from the land register, with the owner's consent, given through an authentic act concluded before the notary. This consent is not required if the right is extinguished by the expiry of the term shown in the registration or by death or, where appropriate, the cease of the legal existence of the holder, in the case of legal persons".

This case of termination of the periodic property applies only if the object of the periodic property is a real estate registered in the land register.

In Article 692 of the Civil Code, it is expressly provided that the removal from the land register is made "pursuant to the acquirement by a single person of all the shares from the right of periodic property, as well as in other cases provided by law".

Through the acquirement by a single person, be it one of the co-owners or a third party, of all the shares from the property right, the periodic property is transformed into a pure and simple property, without affecting the perpetual nature of the property right.

Periodic property may also terminate in other ways provided by law (disappearance of the good, eminent domain, etc.).

Although not explicitly stated, periodic property will also cease if the parties agree upon its transformation into a regular joint ownership. In this particular situation, in the act through which the periodic property is terminated, one must mention, expressly and explicitly, the fact that the use of the good will no longer be exercised successively and repetitively by all the coowners, but simultaneously and continuously.

\section{“Időszakos tulajdon” kérdésköre a romániai Polgári Törvénykönyvben - Összefoglaló} Időszakos vagy megosztott idejü tulajdonlás a közös tulajdon speciális esete új szabályként került a román polgári törvénykönyvbe 2011. október elsejétől.

A tulajdonjog részjogosítványai nem feltétlenül egyformán és egyidejüleg gyakorolhatók. A tulajdon részjogosítványai közül a birtoklás annak ellenére folyamatosnak tekinthető, hogy egymást követő időszakok, szünetek vannak az ingóságok használatában.

Külön fejezetben kerül bemutatásra az időszakos tulajdon fogalma, meghatározása.

Az időszakos tulajdon több módon is keletkezhet, így megállapodással vagy végrendeleti örökléssel. Bemutatásra kerül, hogyan gyakorolhatja a tulajdonos ebben a tulajdonosi 
formában a tulajdoni részjogosítványokat. A polgári perrel kapcsolatos szabályok körében ismerhetjük meg a jogviták elrendezési lehetőségeit, így a társtulajdonos kérheti a közös tulajdon megszüntetését, de pénzbeli kompenzációt is követelhet a társtulajdonostól.

[1] See V. Stoica, Drept civil. Drepturile reale principale, Humanitas Publishing House, Bucharest,vol. 2, 2006, 118.

[2] For an analysis of the periodic property, see I. Lulă, Observaţii asupra reglementării proprietăţii periodice în noul Cod civil, in Dreptul no. 1/2012, 60-76; V. Pătulea, Legea nr. 282/2004 privind protecţia dobânditorilor unui drept de utilizare a unor bunuri imobiliare, in Dreptul no. 1/2005, 5-12; B.C. Stoica, S. Stoica, Investiţiile imobiliare in regim „time share", intre miraj şi posibilităţi de implementare, in P.R. no. 5/2004, 212-227; I. Popa, Coproprietatea spaţio-temporală, in P.R. no. 5/2004, 227-240; L. Stănciulescu, Particularităţile contractelor de locaţiune sezonieră, reglementate de Legea $n r$. 282/2004 privind protecţia dobânditorilor cu privire la unele aspecte ale contractelor purtând asupra dobândirii unui drept de utilizare pe durată limitată a unor bunuri imobiliare, in R.R.D.C. no. 9/2004, 23-31; C. Toader, Contractul de time-sharing, acum reglementat şi în România, in P.R. no. 9/2004, 153-183; T. Sâmbrian, Proprietatea în sistem ,,time sharing”proprietate periodică - o nouă modalitate a dreptului de proprietate, in Dreptul no. 5/1997, $35-44$.

[3] See I. Popa, Coproprietatea spaţio-temporală,loc. cit., 236. The French law uses the concept of multiownership - "multipropriété", see J.P. Rousselle, La multipropriété, in La Revue du Notariat, Montréal, vol. 87, no. 5-6/1985, apud I. Popa, loc. cit., 228, note 2. The French legislator regulates the companies allotting real estate time-share (sociétés d'attrribution d'immeubles en jouissance à temps partagé), which confer the associates, holders of shares, the right to use during a fractioned time lapse part of the real estate. If an associate holds all the time lapses of the same apartment, he/she will be able to leave the company, asking to be alloted that apartment in exclusive ownership (the right to withdraw). The right of the associates is a right of claim in relation to the company and corresponds to the associates' right over the holding or shares. The right is limited to the duration of functioning of the company and the duration of the quality of associate. For a presentation of joint property through the regulation of the different types of real estate companies, see $\mathrm{Ch}$. Larroumet, Droit civil, Les biens, Droits réels principaux, Ed. Economica, 5- éme éd., Paris, 2006, 412-434.

[4] See V. Stoica, Drept civil. Drepturile reale principale, Humanitas Publishing House, Bucharest,vol. 2, 2006, 118.

[5] V. Stoica, op.cit., vol. 2, 118. The author is of the opinion that "taking into account the specificity of the exercise of the use, even if it is not impossible from the point of view of legal logic to conceive the usucapio of the periodic property, nevertheless, from a practical point of view, such a consequence would be hard to accept".

[6] Idem, 119.

[7]Idem, 120. The author considers that, if by means of the joint ownership agreement, the time units in which the use shall be exercised are not determined, it can be said that we deal with a regular joint ownership, with the consequence of recognizing the right to request the partition in favour of any of the holders. It might be considered that, in this case, the agreement by which the parties have understood to give rise to the periodic property, without determining, either initially, or subsequently, the time unit affected to the use by each party, has the legal significance of an agreement of postponement of the division, which might be restricted to 5 years, if it exceeds this period. The consequence of these claims is that there can be no periodic property, regardless of the fact that the parties qualify it as such, when the 
time slots in which is exercised the use of each of the co-owners are not clearly determined. The provisions governing periodic property are derogatory from those which govern regular joint ownership.

[8] See F. Zénati, Notă, in RTDciv. no. 3/1988, 588; F. Zénati, Notă, in RTDciv. no. 3/1993, 614-616, apud D. Chirică, Posibilitatea exercitării acţiunii în revendicare de către un singur coindivizar, in Dreptul no. 11/1998, 24, text and note 16; J.L. Bergel, M. Bruschi, S. Cimamonti, Traite de droit civil. Les biens, Ed. LGDJ, Paris, 2000, 497-500; C. Larroumet, op. cit., 2004, 152-155; Ph. Malaurie, L. Aynès, Droit civil. Les biens, Ed. Defrénois, Paris, 2003, 200.

[9] See R. Sanilevici, I. Macovei, Consecinţele vânzării lucrului altuia în lumina soluţiilor practicii judiciare, in R.R.D. no. 2/1975, 38; D. Chirică, Posibilitatea exercitării ..., loc. cit., 26; D. Chirică, Drept civil. Succesiuni și testamente, Ed. Rosetti, București, 2003, 483-484, text and note 1 .

[10] See Fr. Deak, Tratat de drept civil. Contracte speciale, Universul Juridic Publishing House, Bucharest, 2001, 61, text and note 1. For the solution of the relative nullity of the entire act, on the grounds of sale of another's property, see C.S.J., civil section, decision no. 2369/1992, in Dreptul no. 10-11/1993, 112-113.

[11] See V. Stoica, op. cit., vol. 2, 2006, 79-82.

[12]See V. Stoica, op. cit., vol. 2, 2006, 74-77.

[13]Ibidem.

[14]See I. Lulă, Opinii privitoare la posibilitatea exercitării acţiunii în revendicare de către un singur coproprietar, in Dreptul nr. 4/2002, 77.

[15]See I. Lulă, Opinii privitoare la posibilitatea exercitării acţiunii în revendicare ..., loc. cit., 79,83 .

[16]For a contrary opinion, see D. Chirică, Posibilitatea exercitării acţiunii în revendicare ..., loc. cit., 28.

[17]See D. Chirică, Posibilitatea exercitării acţiunii în revendicare ..., loc. cit., 30.

[18]Ibidem.

[19]Idem, 29. 